\title{
OPTIMISATION AND EVALUATION OF THE EFFECT OF BAMBARA GROUNDNUT ADDITION ON THE NUTRITIONAL QUALITY AND FUNCTIONAL PROPERTIES OF AMARANTH GRAIN-BASED COMPOSITE FLOUR
}

\author{
- Research paper - \\ Olugbenga Olufemi AWOLU ${ }^{1}$, Eunice Yetunde OLOKUNSUSI \\ Department of Food Science and Technology, Federal University of Technology, Akure, \\ Nigeria
}

\begin{abstract}
Nutritional quality and functional properties of composite flour consisting amaranth grain, bambara groundnut, carrot and rice bran flours were evaluated. The dependent variables were optimized using optimal mixture model of response surface methodology. Amaranth grain flour $(70-80.75 \%)$, bambara groundnut flour (15-25\%), carrot flour (2-5\%) and rice bran (2-10\%) were the independent variables. From the results, very high protein content (about $40 \%$ ) was obtained when the bambara content inclusion was $25 \%$. Bambara groundnut flour inclusion up to $15 \%$ also resulted in high protein contents $(\leq 37 \%)$. Supplementation of the composite flour with high carrot flour content (up to 10\%) also enhanced the protein content when the bambara groundnut content was low. High carrot flour inclusion had the highest positive effect on the crude fibre content (3.7-3.9\%) followed by rice bran and bambara groundnut flours in that order. Bambara groundnut had highest positive effect on the ash content; followed by carrot and rice flours. While amaranth grain, carrot and rice bran significantly $(\mathrm{p} \leq 0.05)$ affect the proximate and functional compositions, bambara groundnut had the highest and best effect on the proximate, functional, mineral properties as well as the amino acid profile of the composite flour.
\end{abstract}

Keywords: amaranth grain, amino acid profile, bambara groundnut, minerals, nutritional quality, optimized.

\section{INTRODUCTION}

Legumes play important roles in human diet; it has high protein content and beneficial nutritional values (Klupšaitè and Juodeikienè, 2015) They provide well balanced essential amino acid profiles (lysine, leucine, aspartic acid, glutamic acid and arginine) when consumed with cereals which are rich in sulphur-containing amino acids and tryptophan (Joyce, et al., 2010). In addition, legumes provide energy, dietary fibre, protein, minerals and vitamins required for human (Klupšaite and Juodeikiené, 2015). Pulse proteins enhance some functional properties such as solubility index, water and oil absorption capacity and foaming stability of food products, thus increasing its application in baked and extruded ready-to-eat snacks production (Klupšaitė and Juodeikienè, 2015; Joyce, et al., 2010). Bambara groundnut is a legume rich in iron and calcium in addition to protein, lysine and methionine (Elegbede, 1998).
Amaranth is an under-utilized pseudo-cereal. It has high protein content $(130-206 \mathrm{~g} / \mathrm{kg})$ with high lysine (49-61 g/kg protein) content and about $45 \%$ sulphur containing amino acids (methionine and cysteine). In addition, amaranth has high fat content $(30-80 \mathrm{~g} / \mathrm{kg})$, ash $(25-44 \mathrm{~g} / \mathrm{kg})$ and iron $(72-174 \mathrm{mg} / \mathrm{kg})$ making it a suitable composite flours component for the production of snacks (Bodroža-Solarov et al., 2008).

Carrots are rich sources of vitamin B complex, $\beta$-carotene, dietary fibre, minerals (calcium, potassium and phosphorus) in addition to high carbohydrate content making it a source of energy (Singh et al., 2006). Consumption of carrot is increasing due to its antioxidant and anticancer properties. Carrot pomace, a byproduct of carrot juice processing is being utilized in the development of baking products (Kumar et al., 2010).

Rice bran obtained during rice processing and previously considered a waste is being increasingly utilized as a result of discoveries that rice bran contains bulk of nutrients making

${ }^{1}$ Corresponding author. E-Mail address: ooawolu@ futa.edu.ng 
it a source of low cost nutrient when processed for human consumption. In addition, rice flour contains dietary fibre $(27 \%)$ which has been found to be beneficial in prevention of cardiovascular disease, diabetes, diverticulosis and colon cancer. It also has laxative and cholesterol-lowering ability.

During this study composite flour from bambara groundnut flour supplemented with amaranth grain, carrot flour and rice bran is

\section{MATERIALS AND METHODS}

Materials: Amaranth grain (Amaranthus cruentus), Bambara groundnut (Vigna subterranean L), Carrot (Daucus carota) were purchased from Oja Oba, Akure, Nigeria. Rice bran was obtained from rice mills in IgbemoEkiti. All chemicals were of analytical grade.

Experimental design: The experimental design was carried out using optimal model design of Response Surface Methodology (Design expert 8.0.3.1 trial version). The independent variables were amaranth grain flour (70-80.76 $\mathrm{g} / 100 \mathrm{~g})$, bambara groundnut flour (15-25 $\mathrm{g} / 100 \mathrm{~g})$, carrot flour $(2-5 \mathrm{~g} / 100 \mathrm{~g})$ and rice bran flour $(2-10 \mathrm{~g} / 100 \mathrm{~g})$. This generated 20 experimental runs.

Preparation of amaranth flour: Clean amaranth grains $(1 \mathrm{Kg})$ were milled using an attrition mill and sieved in order to obtain fine flour (less than $500 \mu \mathrm{m}$ ). The amaranth grain flour was sealed in a polythene bag and stored at room temperature (Mburu et al., 2012 (Modified)).

Preparation of bambara groundnut flour: Modified method of Nwosu (2013) was used. Bambara groundnuts were manually sorted to remove stones, defective seeds and extraneous materials. It was then soaked in boiled water for $30 \mathrm{~min}$, manually dehulled, oven dried at $65{ }^{\circ} \mathrm{C}$ for $10 \mathrm{~h}$. It was then milled using attrition mill into flour, sieved to a particle size of $0.25 \mathrm{~mm}$. The milled sample was packed in a sealed polyethylene bag and stored at room temperature.

Preparation of carrot flour: Method of Hedren et al., (2002) was used. Fresh carrots were thoroughly washed and extraneous materials removed. Carrot juice was extracted; the pomace was collected for further use. The developed. The study aims to optimise the chemical composition and functional properties of the composite flour. The optimisation was meant to scientifically and statistically arrive at the best blend combination that is rich in protein, crude fibre, minerals and amino acid; which can be adopted for development of new and nutritionally rich baked products.

pomace was oven-dried at $60{ }^{\circ} \mathrm{C}$ until the moisture content of the sample was reduced to $5+1 \%$ (wet basis). The material was milled, sieved using a $2 \mathrm{~mm}$ size sieve, and the flour stored in polythene bag at room temperature.

Preparation of rice bran flour: The method of Ramezanzadeh et al., (2000) was used. The rice bran was thermally treated in order to inactivate endogenous lipases and then stabilized using a microwave oven. The moisture content of raw rice bran was adjusted to $21 \%$ before treatment. About $100 \mathrm{~g}$ of rice bran was packed in a microwave-safe polyethylene bag, subjected to microwave heating at $120^{\circ} \mathrm{C}$ for $3 \mathrm{~min}$, cooled at room temperature and milled into fine flour.

Determination of protein content: Kjeldahl method was used in determining the protein content. Exactly $0.25 \mathrm{~g}$ of sample was weighed into digestion, digested using $4 \mathrm{ml}$ each of $\mathrm{H}_{2} \mathrm{SO}_{4}$ and $\mathrm{H}_{2} \mathrm{O}_{2}$ at $375{ }^{\circ} \mathrm{C}$, thoroughly mixed for about $2 \mathrm{~h}$ until digestion was completed (indicated by a blue-green coloration). About 1 $\mathrm{ml}$ of the digest was pipetted into $25 \mathrm{ml}$ volumetric flask, 3 drops each of polyvinyl alcohol solution and mineral stabilizer were added and made up to the $25 \mathrm{ml}$ mark with distilled water. Exactly $1 \mathrm{ml}$ of Nessler reagent was added till the appearance of pink colour. Nitrogen concentration was spectrophotometrically obtained at $460 \mathrm{~nm}$ (AOAC, 2005). Percentage nitrogen was calculated using Eq. (1) while the crude protein was calculated using Eq. (2) (Table 1).

Determination of crude fibre: Sample was defatted with hexane in Soxhlet refluxing apparatus. Composite flour sample $(1 \mathrm{~g})$ was weighed into $500 \mathrm{ml}$ beaker TCA reagent (100 $\mathrm{ml}$ ) was added, boiled and refluxed for $40 \mathrm{~min}$ from the time boiling started. The digest was filtered and the residue washed six times with 
hot distilled water. The residue was transferred into a porcelain crucible; oven-dried at $100{ }^{\circ} \mathrm{C}$, weighed (A), ashed in a muffle furnace at 600 ${ }^{\circ} \mathrm{C}$ for $6 \mathrm{~h}$, cooled, and re-weighed (B) (AOAC, 2005). Crude fibre was calculated using Eq. (3) (Table 1).

Determination of ash content: The sample was measured into an empty porcelain crucible which was already ignited and weighed. The crucible was placed in a furnace and maintained at a temperature of $600{ }^{\circ} \mathrm{C}$ for $6 \mathrm{~h}$. The crucible was transferred directly to a desiccator, cooled and weighed (AOAC, 2005). The ash content was calculated using Eq. (4) (Table 1).

Determination of moisture content: Exactly $5 \mathrm{~g}$ of sample was weighed into a clean, dried crucible. The crucible with the sample was placed in an oven, dried at $105^{\circ} \mathrm{C}$ for $16-18 \mathrm{~h}$ until constant weight was obtained. It was later cooled in a desiccator and re-weighed (AOAC, 2005). The moisture content was calculated using Eq. (5), where: A-Weight (g) of crucible, lid and sample before drying; B-Weight ( $\mathrm{g}$ ) of crucible, lid and sample after drying; C-Weight (g) of crucible and lid

Determination of bulk density (BD): Method of Maninder et al., (2007) was used. Flour samples $(50 \mathrm{~g})$ were weighed into $100 \mathrm{ml}$ graduated cylinders. The bottom of each cylinder was tapped gently on a laboratory bench 10 times until diminution of the sample level ceases. Bulk density was calculated using Eq. (6) (Table 1).

Determination of Water and oil absorption capacities (WAC and OAC): Water and oil absorption capacities were measured using AOAC (2005) method, and expressed as grams of water or oil bound per gram of the sample.

Determination of least gelation: Method of Coffman and Garcia (1977) was used. The samples $(2 \mathrm{~g})$ were suspended in $100 \mathrm{ml}$ distilled water. Then, $10 \mathrm{ml}$ of each dispersed was transferred into a test tube, heated in a boiling water bath for $1 \mathrm{~h}$, rapidly cooled in a cold water bath and further cooled at $4{ }^{\circ} \mathrm{C}$ for 2 $\mathrm{h}$. The concentration at which the sample will not slip in an inverted test tube is the least gel concentration (LG) of the sample.

Determination of swelling capacity: Method of Abbey and Ibeh (1988) was used. The sample $(1 \mathrm{~g})$ was weighed into a clean dry measuring cylinder and the volume recorded. About $5 \mathrm{ml}$ of distilled water was later added, and left to stand for $1 \mathrm{~h}$. The new volume was then recorded. The ratio of the swollen volume to the ordinary volume of a unit weight of the sample was calculated as the least gelation.

Determination of minerals: The mineral composition of the flour samples were determined using AOAC (2005) methods. Sodium and potassium were determined using flame photometry method while calcium, iron and zinc were determined using atomic absorption spectrophotometry (SOLAR 929 Unicam A.A. Spectrophotometer, UK)

Determination of amino acid profile: The sample was hydrolysed using $6 \mathrm{~N} \mathrm{HCl}$ at 110 ${ }^{\circ} \mathrm{C}$ for $24 \mathrm{~h}$ in a vial vacuum and $\mathrm{N}_{2}$ atmosphere. Excess acid was evaporated under reduced pressure while the amino acids were spectrophotometrically identified at $570 \mathrm{~nm}$.

Table 1. Equations used for analysing the flour characteristics

$$
\begin{gathered}
\text { \%Nitrogen }=\frac{\text { concentration } \times 0.0075}{\text { weight of sample }(\mathrm{g})} \\
\text { Crude protein }=\% \text { nitrogen } \times 6.25 \\
\% \text { Fiber }=\frac{(\text { weight } A)-(\text { weight } B)}{1} \times 100 \\
\text { Ash } \%=\frac{(\text { weight of crucible }+ \text { ash })-\text { weightof empty crucible }}{\text { weight of sample }(\mathrm{g})} \times 100 \\
\% \text { Moisture content }=\frac{A-B}{A-C} \times 100 \\
\text { Bulk density }\left(\frac{g}{\mathrm{~cm} 3}\right)=\frac{\text { weight of sample }(\mathrm{g})}{\text { volume of sample }(\mathrm{cm})}
\end{gathered}
$$




\section{RESULTS AND DISCUSSIONS}

The moisture, ash, fibre and protein contents of composite flour

The moisture content ranged from $4.655 \mathrm{~g} / 100$ $\mathrm{g}$ to $9.385 \mathrm{~g} / 100 \mathrm{~g}$. This value is within the acceptable range for flour which is less than or equal to $10 \mathrm{~g} / 100 \mathrm{~g}$. The results showed that the samples were shelf stable (Bugusu et al., 2001). The model terms AB (A-B) are significant $(\mathrm{P} \leq 0.05)$. The $\mathrm{R}^{2}$ and adjusted $\mathrm{R}^{2}$ value were 0.9128 and 0.6688 respectively. The final equation showing the interaction of moisture and variables is given in Eq. (7).

The ash content ranged from 1.881 to 3.921 $\mathrm{g} / 100 \mathrm{~g}$. Similar results have been obtained for composite flour consisting cereals, legumes and fibre sources (Awolu et al., 2017; Awolu et al., 2016; Awolu et al., 2015). Bambara groundnut greatly contributed to the ash content (indicated by the red-coloured part of Figures $1 \mathrm{a}$ and $1 \mathrm{~b}$ ) of the composite flour, and hence, of baked products. Awolu and Oseyemi (2006) also reported the same observation. High ash content is advantageous in the preparation of weaning food formulation (Omoba et al., 2013). The final equation representing the interaction of ash with the variables is shown by Eq. (8).

The crude fibre content ranged from 1.55 to $3.981 \mathrm{~g} / 100 \mathrm{~g}$. Carrot had highest contribution to the crude fibre followed by bambara groundnut (Figures 1c, d). This implies that pulses need to be reinforced with a fibre source in order to produce composite flour high in fibre content and sufficient to meet recommended daily requirement (Awolu et al.,
2015). The recommended crude fibre content in flours is less than $5 \mathrm{~g} / 100 \mathrm{~g}$ (Omoba et al., 2013). High fibre content has been reported to be advantageous for those with gastro intestinal disorder and cardiovascular diseases (Aman et al., 1994). It has also been reported to enhance the farinograph constituency in flour (Iancu and Jâşcanu, 2003). The model (quadratic) and model terms, (linear mixture, $\mathrm{AB}$ and $\mathrm{BC})$ are significant $(\mathrm{P} \leq 0.05)$. The lack of fit is not significant $(\mathrm{P} \geq 0.05)$ as required. The $\mathrm{R}^{2}$ and adjusted $\mathrm{R}^{2}$ values were 0.7535 and 0.6397 respectively. The final equation representing the interaction of fibre and the variables is shown by Eq. (9).

The protein content ranged from 33.725 to 40 $825 \mathrm{~g} / 100 \mathrm{~g}$. The protein content is high which might be as a result the of presence of bambara groundnut and amaranth (Amaranthus cruentus) grain (Bodroza-Solarov, 2001) in the composite flour. Studies have also reported high protein content of composite flour and baked products with the addition of legumes like kersting's groundnut, bambara groundnut, soybean (Awolu et al., 2017; Awolu and Oseyemi, 2016; Awolu et al., 2015). Protein also enhances the rheological properties of composite flours (Gruss, 2009). This study supports the report that pulses are good sources of plant protein (Figures 1e, f). In addition, carrot also enhanced the protein content. The model (cubic mixture) and model terms (linear mixture and $\mathrm{AB})$ were significant $(\mathrm{P} \leq 0.05)$. The $\mathrm{R}^{2}$ and adjusted $\mathrm{R}^{2}$ were 0.9310 and 0.7810 respectively. The final equation representing the interaction of protein with the variables is shown by Eq. (10).

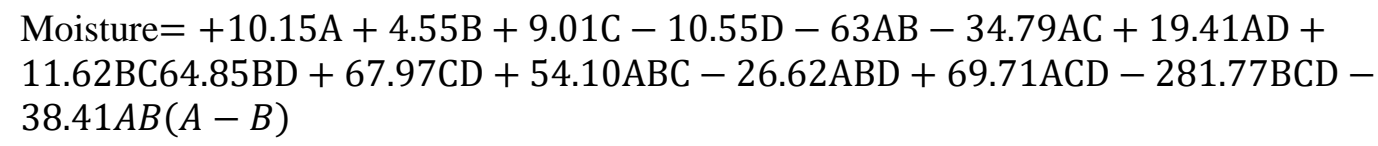

Ash $=+3.95 A+4.92 B+32.74 C-12.07 D 18.38 A D-53.50 B C+51.69 B D+13.05 C D+$ $130.06 A B C-79.56 A B D+146.14 A C D-255.22 B C D$

FibreF $=+1.92 A+1.66 B+0.87 C+4.92 D+6.62 A B+10.50 A C-.84 B D$

Protein $=37.07 A+41.46 B-18.78 C+74.41 D-18.25 A B+136.63 A C-52.88 A D+61.85 B C-$ 132.76BD - 50.84CD - 162.60ABC + 361.36ABD - 433.33ACD + $719.07 B C D$ 


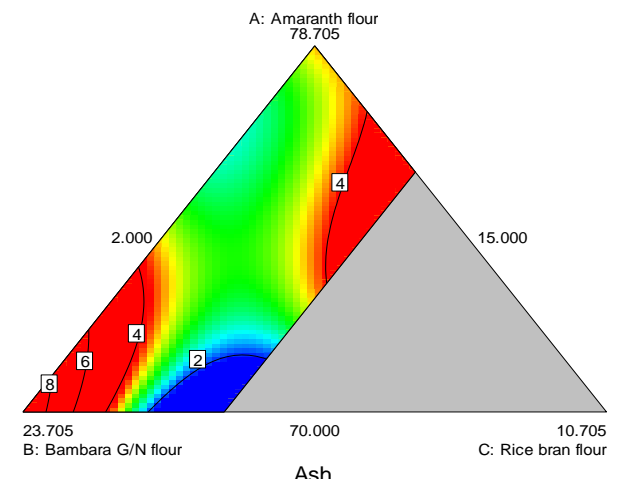

Figure 1a: Contour plot showing the effect of samples $\mathrm{A}, \mathrm{B}$ and $\mathrm{C}$ on the ash content

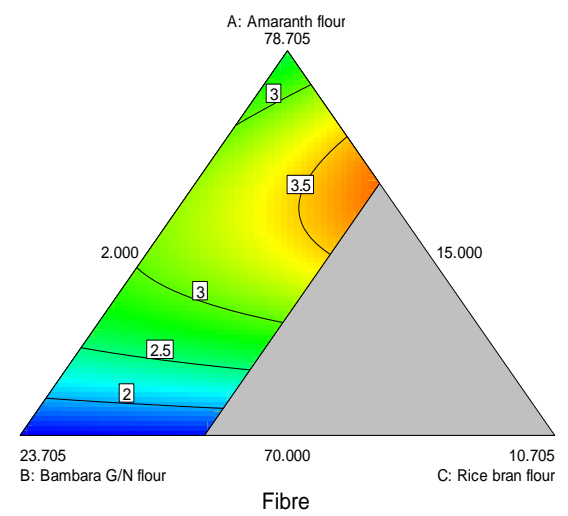

Figure 1c: Contour plot showing the effect of samples $\mathrm{A}, \mathrm{B}$ and $\mathrm{C}$ on the fibre content

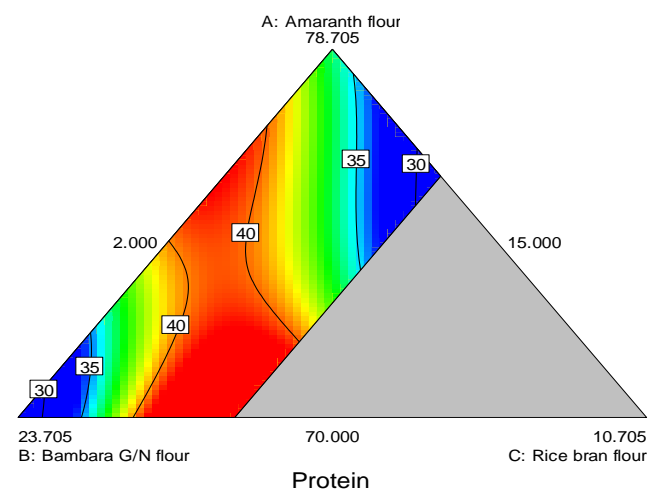

Figure 1e: Contour plot showing the effect of samples $\mathrm{A}, \mathrm{B}$ and $\mathrm{C}$ on protein content

\section{Functional Properties of composite flour}

The WAC of the flour ranged from 1.90 to $3.048 \mathrm{~g} / \mathrm{g}$. Carrot flour and amaranth flour had better effect on the WAC (Figures 2a, b). This indicates that there is a need for the addition of starchy food crops to pulses to give better WAC. High WAC has been shown to promote product cohesiveness (Housson and Ayenor,

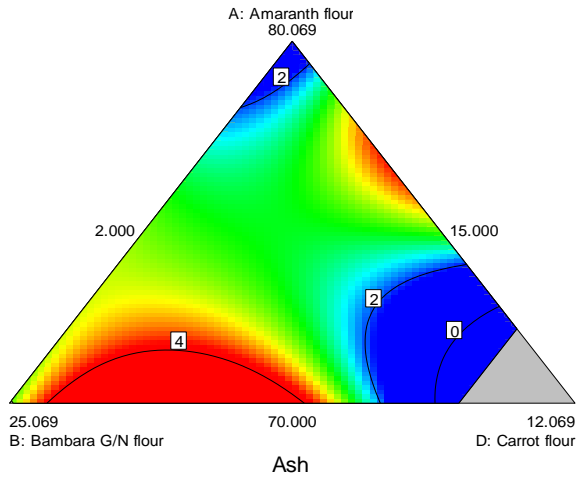

Figure 1b: Contour plot showing the effect of samples A, B and D on ash content

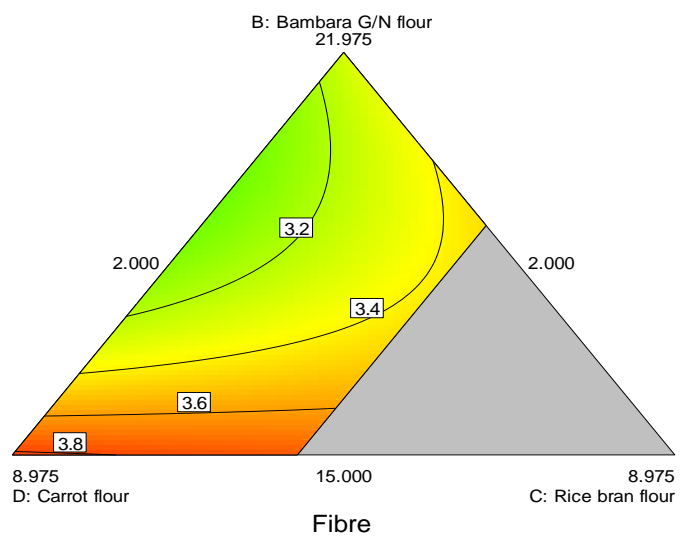

Figure 1d: contour plot showing the effect of samples $\mathrm{B}, \mathrm{D}$ and $\mathrm{C}$ on fibre content

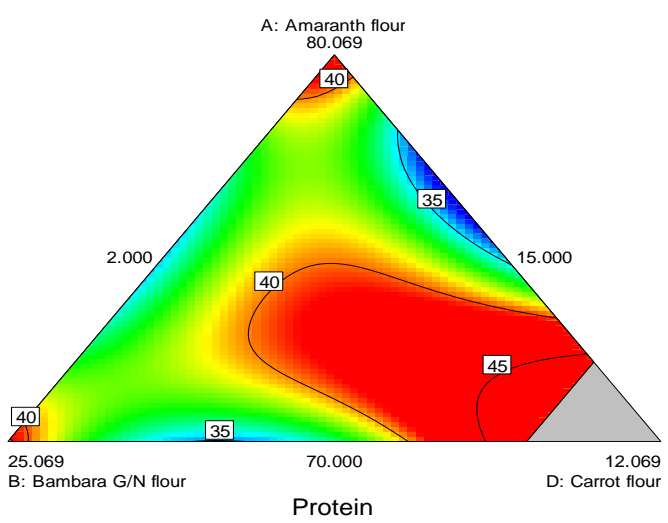

Figure 1f: contour plot showing the effect of samples A, B and D on the protein content

2002). The model (cubic mixture) and model terms $(\mathrm{AC}$ and $\mathrm{BC})$ were significant $(\mathrm{P} \leq 0.05)$. The $\mathrm{P}$-value for lack of fit which is 0.0751 is not significant $(\mathrm{P} \leq 0.05)$. The $\mathrm{R}^{2}$ and adjusted $\mathrm{R}^{2}$ values were 0.9044 and 0.6972 respectively while the final equation representing the interaction of WAC with the variables is shown by Eq. (11). The OAC ranged from 2.507 to $3.066 \mathrm{~g} / \mathrm{g}$. Bambara groundnut flour clearly enhanced the $\mathrm{OAC}$ of the composite 
flour (Figures 2c, d) indicating that pulses, because of its high protein content promotes OAC. It has been established that flour samples with high OAC are better flavour retainer (Chandra and Samsher, 2013). The oil binding capacity of food protein depend upon the intrinsic factors like amino acid composition, protein conformation and surface polarity or hydrophobicity (Chandra and Samsher, 2013). $\mathrm{R}^{2}$ and adjusted $\mathrm{R}^{2}$ values were 0.9915 and 0.9732 respectively. High $R^{2}$ and adjusted $R^{2}$ values is an indication that the independent variables positively impacts the dependent variables. The final equation representing the interaction of OAC with the variables is shown by Eq. (12).

The least gelation capacity ranged from 0.4 to $0.8 \mathrm{~g} / \mathrm{mg}$. Amaranth grain and bambara groundnut flours enhanced the least gelation of the composite flour (Figure 2e). The $\mathrm{R}^{2}$ and adjusted $\mathrm{R}^{2}$ values were 0.8872 and 0.6428 respctively. The final equation representing the interaction of LG with the variables is shown by Eq. (13).

The bulk density (BD) ranged from 0.717 to $0.914 \mathrm{~g} / \mathrm{cm}^{3}$. High bulk density is desirable for greater ease of dispensability and reduction of paste thickness (Amadikwa, 2012). The model terms ( $\mathrm{AB}, \mathrm{AC}$ and $\mathrm{CD})$ were significant $(\mathrm{P} \leq 0.05)$. The $\mathrm{R}^{2}$ and adjusted $\mathrm{R}^{2}$ were 0.8495 and 0.7140 respectively. The final equation representing the interaction of bulk density with the variables is shown by Eq. (14).

The swelling capacity ranged from $0.896 \mathrm{~g} / \mathrm{mg}$ to $1.493 \mathrm{~g} / \mathrm{mg}$. Bambara groundnut and amaranth grain flours had the highest contribution towards the swelling capacity (Figures 2f, g). Swelling power had been related to their protein content (Woolfe, 1992). The model term (ABC) was significant $(\mathrm{P} \leq 0.05)$. The $\mathrm{R}^{2}$ and adjusted $\mathrm{R}^{2}$ were 0.9650 and 0.8893 respectively. The final equation representing the interaction of swelling capacity with the variables is shown by Eq. (15).
$W A C=1.47 A+2.56 B-31.71 C+17.27 D+0.17 A B+0.66 A C-22.80 A D+44.05 B C-$
$54.42 B D-9.77 C D-53.54 A B C+91.60 A B D-115.54 A+250.38 B C D$

$O A C=+2.91 A+3.22 B+22.12 C-4.21 D-1.07 A B-38.33 A C+11.70 A D-27.95 B C+$ $25.99 B D-1.392 E-003 C D+46.29 A B C-52.56 A B D+53.22 A C D-117.52 B C D$

$L G=0.86 A+0.81 B 10.05 C-3.46 D-0.62 A B-20.69 A C+5.34 A D-13.7+14.59 B D+$ $1.95 C D+34.39 A B C-18.85 A B D+40.12 A C D-77.33 B C$

$B D=+0.75 A+0.95 B-0.86 C+0.75 D-0.27 A B+2.32 A C+0.19 A D+1.33 B C-0.30 B D+$ $2.33 C D$

$S C=+1.54 A+1.40 B+6.09 C-2.11 D-2.33 A B-15.65 A C+4.96 A D-8.00 A B D+$ $31.50 A C-68.58 B C D$

\section{Result of optimization}

The two best blends based on the optimization of proximate composition and functional properties were run 4 (70\% Amaranth, 20.5\% bambara groundnut, $3.5 \%$ rice bran, $6 \%$ carrot) and run 6 (70.7\% Amaranth, $25.0 \%$ bambara groundnut, $2.2 \%$ rice bran, $2.05 \%$ carrot).

\section{Mineral composition of composite flour}

The results of the mineral composition of the optimised composite flour are presented in
Table 2. Run 6 with higher bambara groundnut content had the overall better mineral composition in zinc, iron, calcium, sodium, potassium and phosphorus. The result clearly showed that pulses enhance mineral composition of composite flours. This is an advantage over the use of $100 \%$ wheat flour (which had less mineral composition compared to pulses-enriched composite flours). Bambara groundnut, and soybean had been found to improve mineral composition of flour (Awolu and Oseyemi, 2016; Iancu and Jâş̧canu, 2003). 


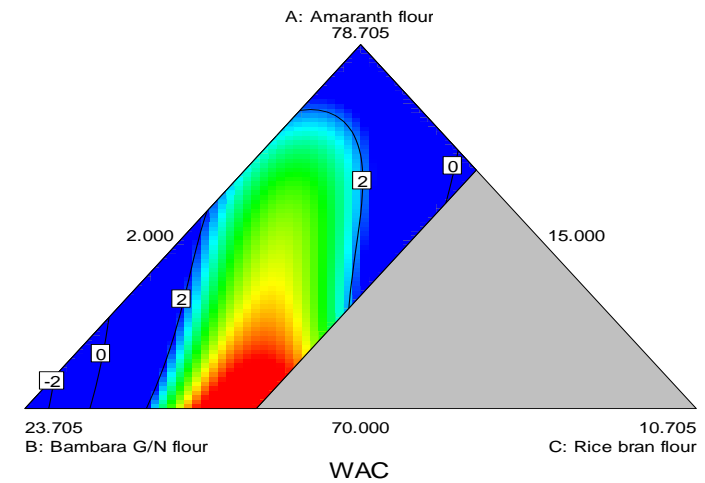

Figure 2a: Contour plot showing the effect of samples $\mathrm{A}, \mathrm{B}$ and $\mathrm{C}$ on WAC

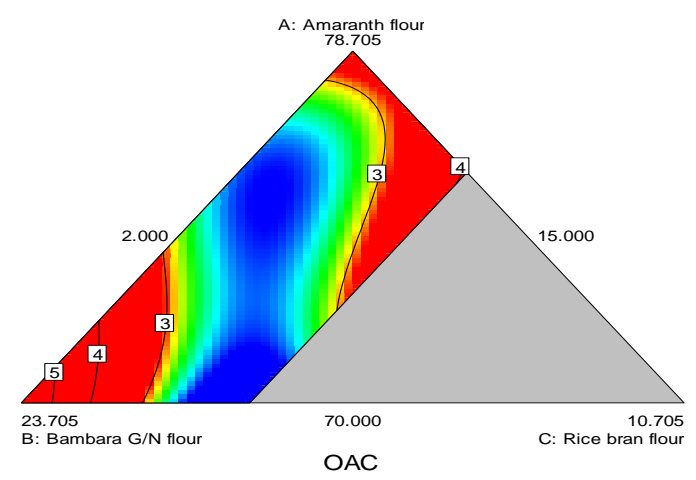

Figure 2c: Contour plot showing the effect of samples $\mathrm{A}, \mathrm{B}$ and $\mathrm{C}$ on $\mathrm{OAC}$

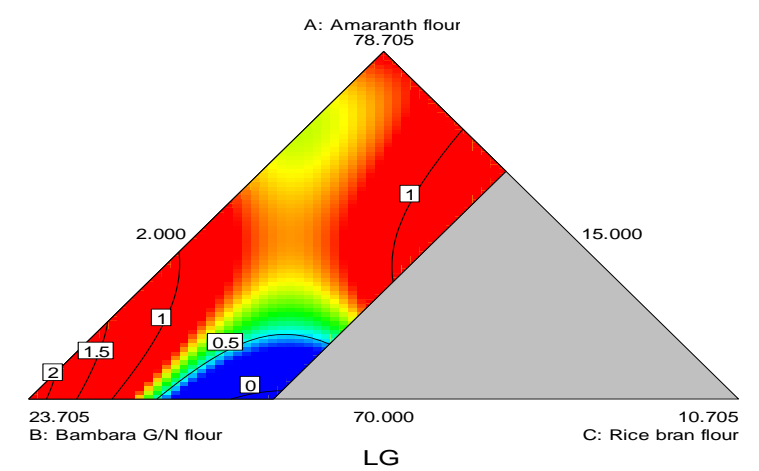

Figure 2e: Contour plot showing the effect of samples $\mathrm{A}, \mathrm{B}$ and $\mathrm{C}$ on $\mathrm{LG}$

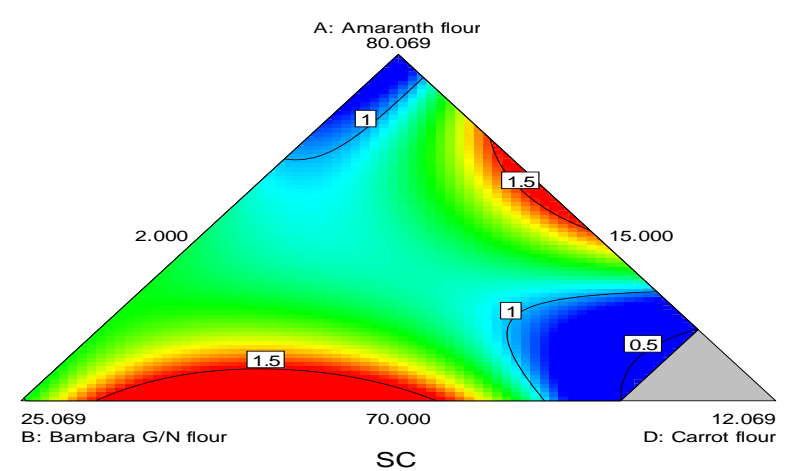

Figure 2g: Contour plot showing the effect of samples $\mathrm{A}, \mathrm{B}$ and D on SC

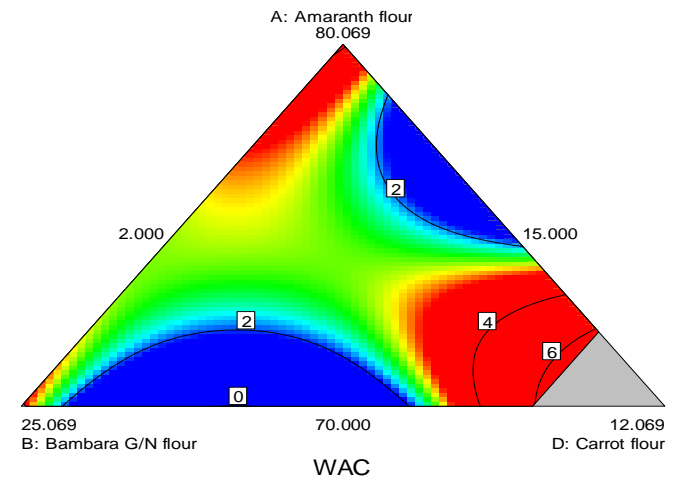

Figure 2b: Contour plot showing the effect of samples A, B and D on WAC

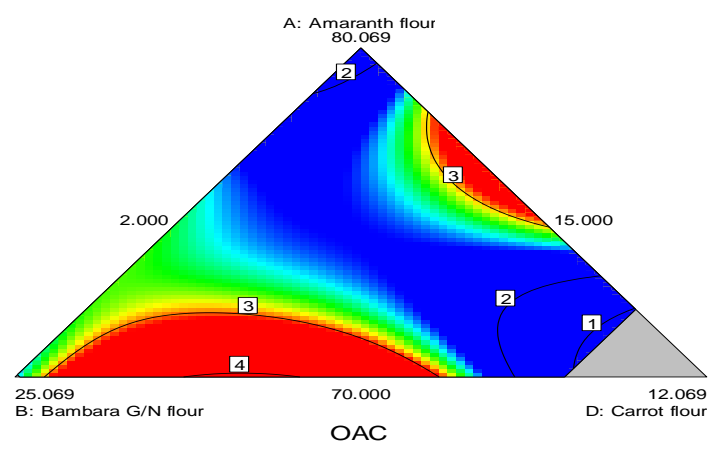

Figure 2d: contour plot showing the effect of samples A, B and D on OAC

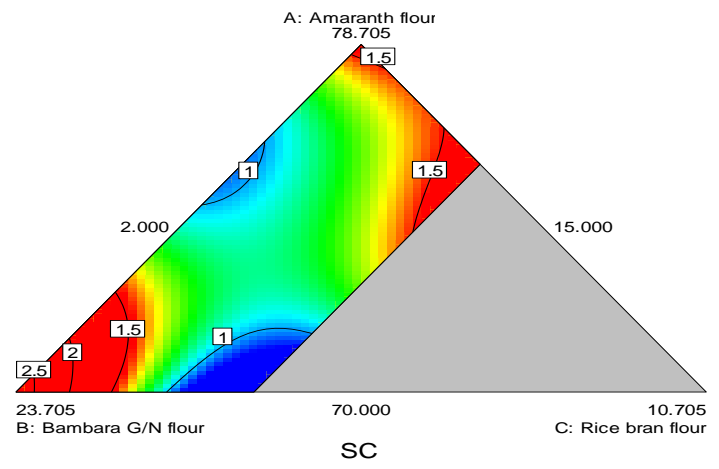

Figure 2f: contour plot showing the effect of samples A, B and C on SC 
Table 2. Mineral Composition of the Composite Flour

\begin{tabular}{|l|l|l|l|l|l|l|}
\hline Run & Zn $(\mathrm{ppm})$ & $\mathrm{Fe}(\mathrm{ppm})$ & $\mathrm{Ca}(\mathrm{ppm})$ & $\mathrm{Na}(\mathrm{ppm})$ & $\mathrm{K}(\mathrm{ppm})$ & $\mathrm{P}(\mathrm{ppm})$ \\
\hline 4 & $1.22 \pm 0.00^{\mathrm{b}}$ & $1.96 \pm 0.00^{\mathrm{b}}$ & $4.80 \pm 0.00^{\mathrm{b}}$ & $9.70 \pm 0.00^{\mathrm{b}}$ & $65.00 \pm 0.00^{\mathrm{b}}$ & $1.32 \pm 0.00^{\mathrm{b}}$ \\
\hline 6 & $1.34 \pm 0.00^{\mathrm{a}}$ & $2.26 \pm 0.00^{\mathrm{a}}$ & $5.00 \pm 0.00^{\mathrm{a}}$ & $25.00 \pm 0.00^{\mathrm{a}}$ & $80.00 \pm 0.00^{\mathrm{a}}$ & $1.43 \pm 0.00^{\mathrm{a}}$ \\
\hline
\end{tabular}

$*$ Values with different superscripts along the same column are significantly different.

Run $4=70 \%$ Amaranth / 20.5\% bambara groundnut / 3.5\% rice bran / 6\% carrot.

Run $6=70.7 \%$ Amaranth $/ 25.0$ bambara groundnut / $2.2 \%$ rice bran $/ 2.05 \%$ carrot.

\section{Amino acid profile of composite flour}

The amino acid contents are presented in Table 3. The selected composite flour (run 6) is rich in lysine, histidine, valine, isoleucine, leucine, methionine, phenylalanine, threonine, and tryptophan. Leucine is the most abundant essential amino acid in the samples. The essential amino acid component is $60 \%$ while the non-essential amino acid component is $40 \%$. This composite flour had successfully eliminated deficiency of methionine (particular to legumes) and deficiency of lysine, threonine and tryptophan (particular to cereals).

Table 3. Amino Acid Profile for Run 6

\begin{tabular}{|ll|lc|}
\hline Essential amino acid & $(\mathrm{mg} / 100 \mathrm{~g})$ & Non- Essential amino acid $(\mathrm{mg} / 100 \mathrm{~g})$ \\
\hline Lysine & 135.38 & Arginine & 235.37 \\
\hline Histidine & 163.37 & Aspartic acid & 435.33 \\
\hline Valine & 280.25 & Serine & 345.36 \\
\hline Isoleucine & 223.25 & Glutamic acid & 122.37 \\
\hline Leucine & 660.26 & Proline & 455.35 \\
\hline Methionine & 120.26 & Glycine & 220.25 \\
\hline Phenylalanine & 263.35 & Alanine & 420.25 \\
\hline Threonine & 242.25 & Cystine & 105.25 \\
\hline Tryptophan & 37.58 & & \\
\hline
\end{tabular}

$*$ Run $6=$ amaranth $70.725 \%$, bambara groundnut $25 \%$, rice bran $2.220 \%$, carrot $2.055 \%$.

\section{CONCLUSIONS}

Incorporation of bambara groundnut has greatly improved the nutritional quality (protein content, ash content, minerals composition and amino acid profile) and functional properties of the composite flour. Specifically, bambara groundnut flour improved the OAC, LG and SC while carrot flour improved the WAC.

The optimum blends were samples with $70 \%$ Amaranth / 20.5\% bambara groundnut / 3.5\% rice bran / 6\% carrot and 70.7\% Amaranth / 25.0 bambara groundnut / $2.2 \%$ rice bran / $2.05 \%$ carrot. The blend of amaranth grain (a pseudo cereal) with bambara groundnut (legume) had successfully overcome the limiting amino acids particular to cereals (lysine, threonine, tryptohan) and legumes (methionine). In the study the values of these limiting amino acids were high (between 37.58 $-135.00 \mathrm{mg} / \mathrm{g}$ )

\section{REFERENCES}

1. Abbey, B.W. and Ibeh, G.O. (1988). Functional properties of raw and heat processed cowpea flour. Journal of Food Science, 53(6), 1775-1791. doi:10.1111/j.1365-2621.1988.tb07840.x

2. AOAC (2005). Official Methods of Analysis International.(18 $8^{\text {th }}$ edition), International, Gaithersburg, Maryland, USA.

3. Aman P., Westerlund E., Theander O. (1994) Determination of starch using thermostable $\alpha$ amylase. In: BeMiller JN,Manners DJ, Sturgeon RJ (eds) Methods in Carbohydrate Chemistry, vol. X.Wiley, New York, pp 111-115.

4. Amandikwa, C. (2012). Proximate and Functional Properties of Open Air, Solar and Oven Dried Cocoyam Flour. International Journal of Agriculture and Rural Development, 15 (2), 988 $-994$. 
5. Awolu, O.O., Oluwaferanmi, P.M., Fafowora, O.I. and Oseyemi, G.M. (2015). Optimization of the extrusion process for the production of ready-to-eat snack from rice, cassava and kersting's groundnut composite flours. LWT Food Science and Technology, 64, 18-24.

6. Awolu, O.O., Omoba, O.S., Olawoye, O. and Dairo, M. (2017). Optimization of production and quality evaluation of maize-based snack supplemented with soybean and tigernut (Cyperus esculenta). Food Science and Nutrition, 5, 3-13.DOI:10.1002/fsn3.359.

7. Awolu, O.O., Osemeke, R.O. and Ifesan, BOT (2016). Antioxidant, functional and rheological properties of optimized composite flour, consisting wheat and amaranth seed, brewers' spent grain and apple pomace. Journal of Food Science and Technology, 53(2): 1151-1163.

8. Awolu, O. O., \& Oseyemi, G. F. (2016). Physicochemical and Rheological Properties of Optimised Cocoyam-Based Composite Flour Comprising Cassava Starch. Acta Universitatis Cibiniensis. Series E: Food Technology, 20(2), 65-84.

9. Bodroža-Solarov, M.: Effects of Genotype and Sowing Date on Yield and Yield Components of the Genus Amaranthus L, Ph.D.Thesis, Faculty of Agriculture, University of Novi Sad (2001), $1-113$.

10. Bugusu, B.A., Campanella, O., Hamaker, B.R. (2001) Improvement of sorghumwheat composite dough rheological properties and breadmaking quality through zein addition. Cereal Chemistry, 78(1):31-35.

11. Coffman, C.W. and Garcia, V.V. (1977). Functional properties and amino acid content of protein isolate form mung bean flour. Journal of Food Technology, 12: 473-484.

12. Elegbede JA (1998). Legumes. Int: Osagie AU, Ou Eka (Eds.). Nutritional Quality of Plant Foods. Post. Harvest. Research Unit, University of Benin, Benin, Nigeria, pp. 53-83.

13. Gruss $\mathrm{T}$ (2009) Ten reasons to use amaranth in your gluten-free recipes. http://glutenfreecooking.about.com/od/nutritionmealplanning/a/amaranth.htm

14. Hedren, E., Diaz, V. and Svanberg, U. (2002). Original communications-estimation of carotenoid accessibility from carrots determined by an in vitro digestion method. European Journal of Clinical Nutrition, 56(5), 425-430.

15. Iancu, M. L., \& Jâşcanu, V. (2003). Additions ror correcting the technological properties of flour and for improving the nutritive value of bread. Acta Universitatis Cibiniensis Series E: FOOD TECHNOLOGY, 7(2), 3-25.

16. Joyce B and Fateman Z (2010). Pulse protein: processing, characterization and application in food and feed. Food Research International, 42(2), 414-437.

17. Klupšaitè, D. and Juodeikienè, G. (2015). Legume: composition, protein extraction and functional properties: A review. Chemine Technologija Nr. 1 (66): 5-12

18. Kumar, N., Sarkar, B. C. and Sharma, H. K. (2010). Development and characterization of extruded product of carrot pomace, rice flour and pulse powder. African Journal of Food Science, 4(11), 703-717.

19. Maninder K, Kawaljit SS, Narpinder S (2007) Comparative study of functional, thermal and pasting properties of flours from different field pea and pigeon pea cultivars. Food Chemistry, 104:259-267

20. Mburu, M.W., Gikonyo, N.K., Kenji, G.M. and Mwasaru, A.M. (2012). Nutritional and functional properties of a complementary food based on Kenyan amaranth grain (Amaranthus cruentus). African Journal of Food Agriculture and Nutritional Development. 12(2): 5959-5977.

21. Nwosu, J.N. (2013). Production and evaluation of biscuits from blends of Bambara Groundnut (Vigna Subterranae) and Wheat (Triticum Eastrum) flours. International Journal of Food Nutrition, 2(1): 4-9.

22. Omoba, O.S., Awolu, O.O., Olagunju, A.I., Akomolafe, A.O. (2013) Optimisation of plantainbrewer's spent grain biscuit using response surface methodology. Journal of Scientific Research and Reports, 2(2), 665-681.

23. Ramezanzadeh, F.M., Rao, R.M., Prinyawiwatkul, W., Marshall, W.E. and Windhauser, M. (2000). Effects of microwave heat, packaging, and storage temperature on fatty acid and proximate compositions in rice bran. Journal of Agriculture and Food Chemistry, 48(2): 464467.

24. Singh, B., Panesar, P. S., \& Nanda, V. (2006). Utilization of carrot pomace for the preparation of a value added product. World Journal of Dairy and Food Science, 1(1), 22-27. 
25. Woolfe, J. (1992). Sweet potato: An untapped food resource, Cambridge University Press. Pg $13 ; 366-372$. 